\title{
HISTOLOGICAL AND CHEMICAL FINDINGS IN KRABBE'S LEUCODYSTROPHY
}

\author{
BY \\ R. M. NORMAN, D. R. OPPENHEIMER, and A. H. TINGEY \\ From the Burden Neuropathological Laboratory, Frenchay Hospital, Bristol, and the \\ Department of Neuropathology, the Radcliffe Infirmary, Oxford
}

The familial disease of the cerebral white matter named after Krabbe (1916) may be distinguished histologically from other leucoencephalopathies of early life by the presence of conspicuous nests of macrophage cells, some of large size with several peripherally placed nuclei, lying closely packed around the smaller vessels of the cerebral white matter. The large multinucleated cells were designated 'globoid cells' by Collier and Greenfield (1924), and Greenfield (1958) later gave the name 'epithelioid' to smaller mononuclear cells which also help to form the perivascular packets. Both types of cell contain a substance having the histochemical properties of a glycolipid bound to protein (Diezel, 1955; Stammler, 1956). Since mononuclear, or sometimes multinuclear, cells containing complex lipid material may be present in other types of diffuse sclerosis (Ferraro, 1927; Seitelberger, 1960), it is necessary to stress in the definition of Krabbe's disease this relationship of the cell packets to the smaller vessels. If this criterion is applied, there are some 25 recorded cases of this disorder (Hallervorden, 1957), all of which concerned children dying before the age of 7 years. There are also two, more doubtful, sporadic cases which have been described in adults (Verhaart, 1931; Guillain, Bertrand, and Gruner, 1941). This list includes the earliest case on record, that of Bullard and Southard (1906), who described typical neuropathological findings in a boy dying at the age of $6 \frac{1}{2}$ years after an illness lasting one year.

There has been much speculation as to the origin and function of the globoid cells, whether they are formed by microglia engaged in engulfing and transporting products of myelin breakdown to the vessels, or whether they are derived from the vascular adventitia and, if so, whether their abnormal lipid content is a phenomenon of primary storage, as in a lipidosis. The recent observations of Stammler (1956) strongly suggest that the perivascular globoid and mononuclear cells are both adventitial deriva- tives and our cases throw further light on this important feature.

The histological observations on these cases have been supplemented by chemical analysis of the cerebral cortex and white matter, using a method by which neutral or true cerebroside may be separated from other glycolipids. We have found this to be present in relatively normal amount despite the severe degeneration of the white matter and a substantial loss of other myelin lipids.

\section{Case Reports}

Case 1.-A boy aged 9 months at death was the second child, an elder sibling being healthy. The parents were normal and not blood relations. He was born at full term and weighed $7 \frac{1}{2} \mathrm{lb}$. Progress was normal until the sixth month when feeding became difficult and the legs were noted to be stiff. On admission to hospital two weeks later, he showed head retraction, marked spasticity of the limbs, and extensor plantar responses. The optic discs were slightly pale but he appeared alert and could follow objects with his eyes. A ventriculogram showed slight dilatation of the frontal horns and much subdural air. Examination of the cerebrospinal lumbar fluid showed no cells, protein $270 \mathrm{mg}$. per $100 \mathrm{ml}$; fluid from the right ventricle, 40 cells, $170 \mathrm{mg}$. of protein per $100 \mathrm{ml}$., and from the left ventricle 3 cells, $170 \mathrm{mg}$. protein per $100 \mathrm{ml}$. A radiograph of the spine showed unfused neural arches down to D9. During the last months of life a steady deterioration ensued. Muscle tone varied but the usual posture was one of opisthotonus. Death followed an attack of bronchopneumonia.

Case 2.-A girl aged 6 months at death was the younger sister of the first patient (Case 1). Birth was normal and the birth weight $8 \frac{1}{4} \mathrm{lb}$. She appeared to be developing normally until the age of 3 months, when jerky movements were noticed in the arms and legs and she became difficult to feed. On admission to hospital at the age of 4 months, she was found to be an irritable child with a high-pitched cry. The limbs jerked frequently. There was no spasticity at this stage. The plantar responses were extensor. Lumbar puncture yielded a slightly bloodstained fluid with a protein of $340 \mathrm{mg}$. per $100 \mathrm{ml}$. Tests for toxoplasmosis were negative. There was no 
abnormal aminoaciduria on chromatography. During the next weeks she developed a generalized spasticity and became opisthotonic. She had increasing difficulty in swallowing and death occurred after a respiratory infection.

Case 3.-A boy aged 13 months at death was the firstborn child of healthy parents who were not blood relations. He was born by forceps delivery owing to foetal distress, but appeared to make normal progress until he was about 2 months old, when vomiting and feeding difficulties began and the legs were noted to be stiff. At the age of 6 months he was found to be about three months retarded in his motor and adaptive behaviour (Griffiths mental development scale). Progressive mental deterioration and spasticity developed and death occurred from bulbar paralysis. Shortly before death the blood of the child and mother were examined for toxoplasmosis with negative results.

\section{Examination of the Central Nervous System}

With certain exceptions to be noted later the pathological features of these brains were closely similar and will be described together to give a composite picture.

Macroscopic.-Brain weights (unfixed) were in Case 1, 666 g., in Case 2, 616 g. The meninges and convolutional pattern were not remarkable. In Case 2 the optic nerves were unduly large. On section, the lateral and third ventricles were slightly enlarged. The white matter of the cerebral hemispheres was tough and greyish except for the subcortical $U$ fibres of Cases 1 and 3 which appeared to be preserved. The cerebellar white matter was sclerosed and in Case 3 the folia were slightly shrunken, especially on the dorsal surface. The brain-stem and spinal cord were also firmer in consistency than the normal and in Case 3 the distinction between grey and white matter was obscured. Prominent lateral sulci were present in the spinal cords.

Microscopic.-Representative blocks were examined in celloidin, paraffin and frozen sections, stains for nerve cells, axis cylinders, myelin, fibrous neuroglia, lipid and carbohydrate being employed.

Changes in White Matter.-Frozen sections stained by Kultschitsky-Pal revealed a severe loss of myelinated fibres in the cerebral and cerebellar white matter (Figs. 1 and 2). In Case 3 virtually the whole of the centrum ovale was affected, though the $U$ fibres were well preserved. In Case 2 the $U$ fibres were not so strikingly spared (Fig. 3). In Case 1 the loss was most marked in the central regions of the hemispheres, and the occipital lobe was relatively well myelinated except for the optic radiation and periventricular fibres (Fig. 5).

In the basal ganglia a diffuse but incomplete loss of fibres was seen in the thalamus. The globus pallidus in Cases 1 and 2 was similarly affected, but in Case $3 \mathrm{D}$ the changes were more patchy. The striatum in Cases 1 and 2 was almost devoid of fibres, but ino Case 3 the compact bundles in the putamen were remarkably preserved (Fig. 6). The internal capsule was severely damaged in all cases, while the optic tracts retained some of their peripheral fibres (Fig. 6). The mammillothalamic fasciculus and the stria medullaris were well myelinated.

In the brain-stem the cerebral peduncles (Fig. 7) and pyramids had completely degenerated, and the latter contained small cavities in Cases 2 and 3. The restiform body, the transverse fibres of the pons, the medial lemniscus and inferior olivary fibres, were well preserved in Case 1 only.

The superior cerebellar peduncles were severelyos affected. There was a striking preservation of the $\overrightarrow{0}$ intramedullary portions of the cranial nerves, and of the medial longitudinal bundles.

Myelination of the spinal cord was poor through $\frac{\text { ? }}{7}$ out, particularly in Case 2. The posterior columns in general were less affected than other tracts. Thei pyramidal tracts were severely damaged, while $e_{\omega}^{+}$ elsewhere the fibre loss was diffuse and incomplete.

Loss of axis cylinders generally went hand in ha with demyelination, though it was noted that coh siderable numbers of fibres remained in the severeydemyelinated internal capsules and optic nerves.

A fibrous gliosis of remarkable density wasso

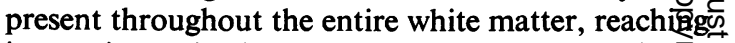
its maximum in the fully degenerated areas (Figs and 8). In the latter situations the cellular prolifera-g tion was also extremely marked, the astrocytic nuclei being unusually large and pleomorphic. The cello bodies were swollen and stained faintly with the periodic-acid-Schiff (P.A.S.) method. Oligodendro-음 glia had largely disappeared from the sclerosed areaş but was present in less affected parts of the white@ matter.

Microglial cells, many with swollen processes staining pink with P.A.S., were numerous in the $\mathrm{U}$ fibres and less affected areas of the cerebral white matter. In Case 2 the corpus callosum and pillars of the fornix contained large aggregations of micro $=\frac{7}{0}$ glial cells showing droplets of neutral fat and doublyo refractile lipid in their processes, but fully formed. fat-granule cells were rare. The scarlet-staining lipid occasionally seen in the walls of vessels in the white substance was mainly in the form of extracellularo droplets.

Globoid and epithelioid cell packets were ao characteristic feature of all cases (Fig. 9 to 11). The former were large round cells, $20-40 \mu$ in diameter $N$ with several peripherally placed, oval nuclei (Fig. 12) N Their homogeneous cytoplasm stained pink with 

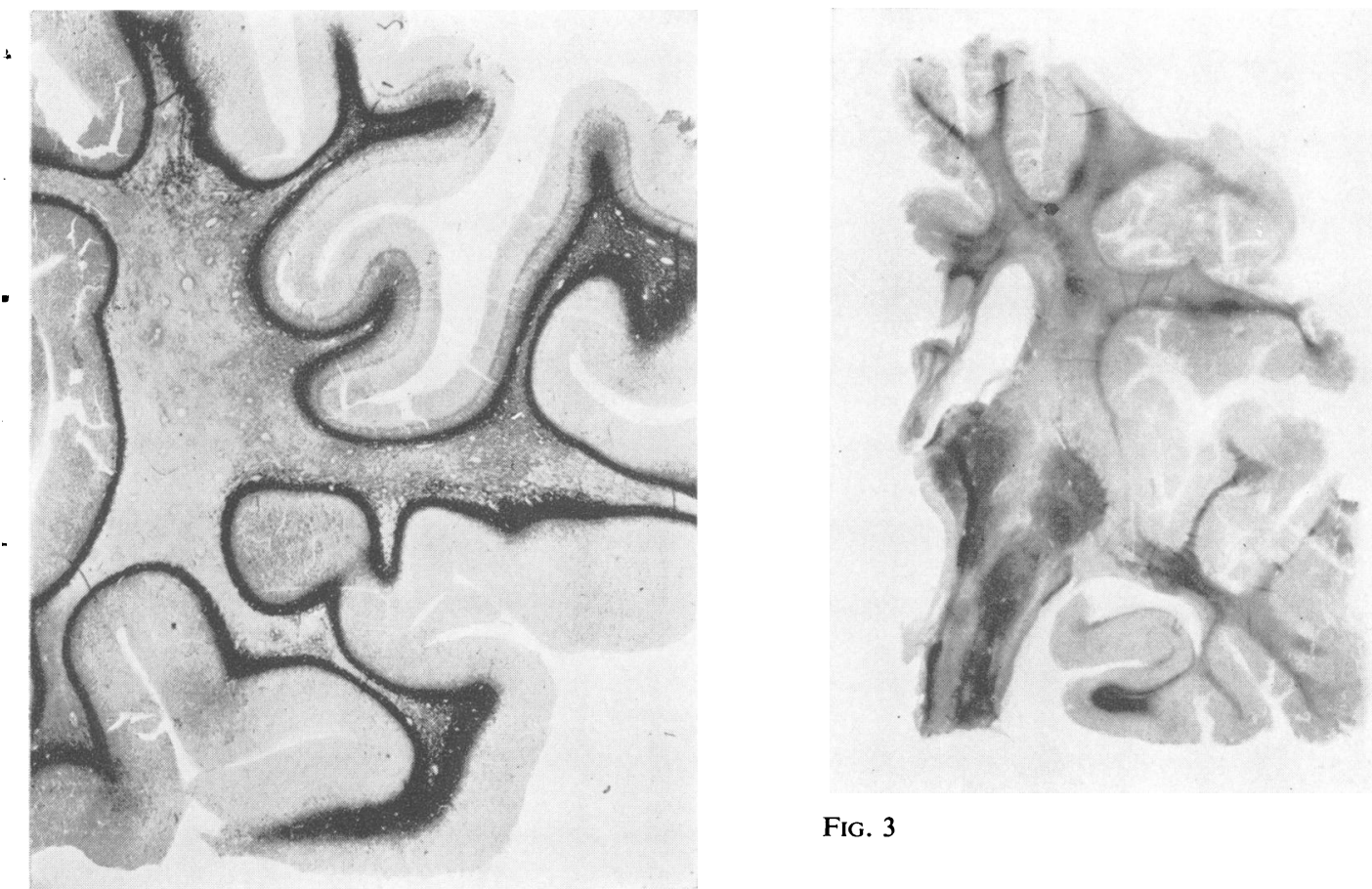

FIG. 1
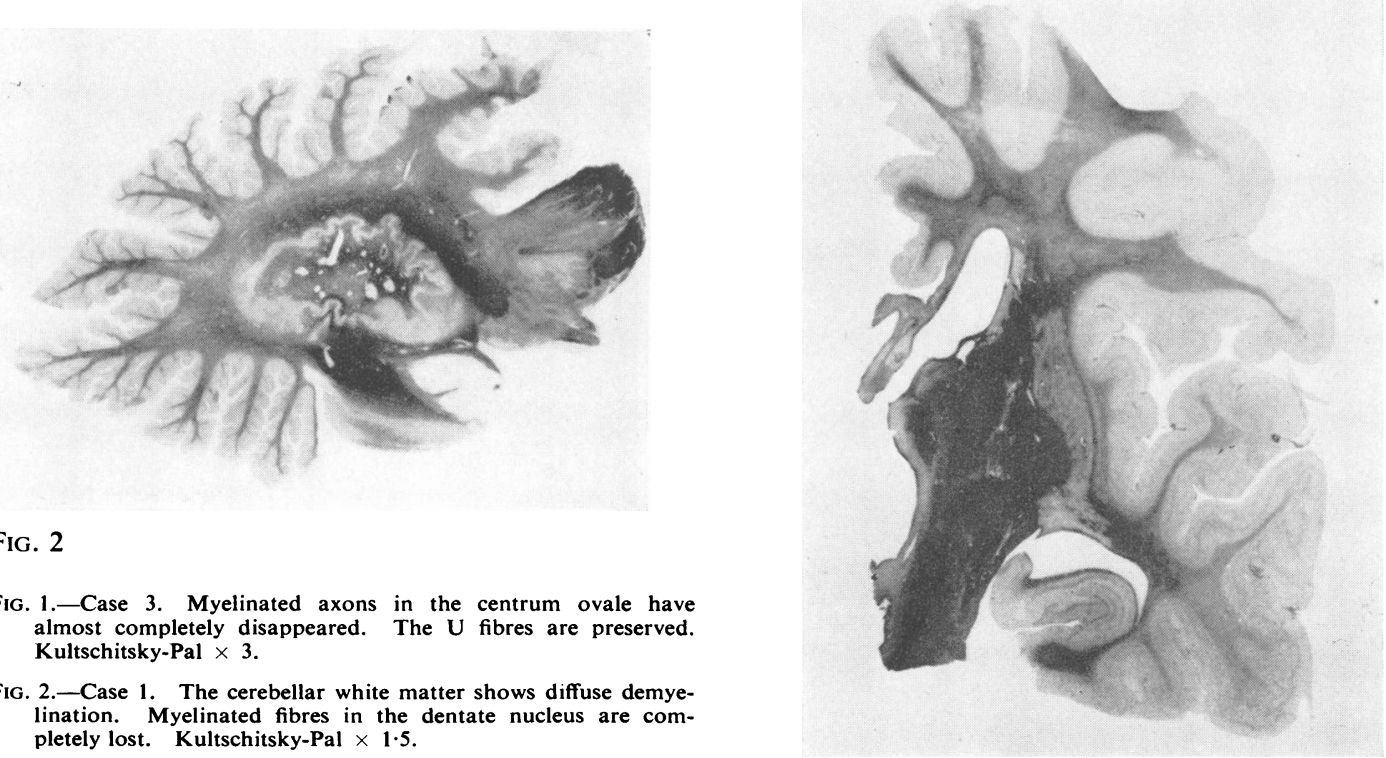

Fig. 2

FIG. 1.-Case 3. Myelinated axons in the centrum ovale have almost completely disappeared. The $\mathrm{U}$ fibres are preserved. Kultschitsky-Pal $\times 3$.

FIG. 2.-Case 1. The cerebellar white matter shows diffuse demyelination. Myelinated fibres in the dentate nucleus are completely lost. Kultschitsky-Pal $\times 1 \cdot 5$.

Fig. 3.-Case 2. Diffuse demyelination of centrum ovale with but little relative preservation of the $U$ fibres. Kultschitsky-Pal $\times$

FIG. 4

FIG. 3 0.9 .

FIG. 4.-Case 2. Corresponding section to Fig. 3. Dense fibrous gliosis in the centrum ovale, thalamus, globus pallidus, and cerebral peduncle. Holzer $\times 0.9$. 
FIG. 5

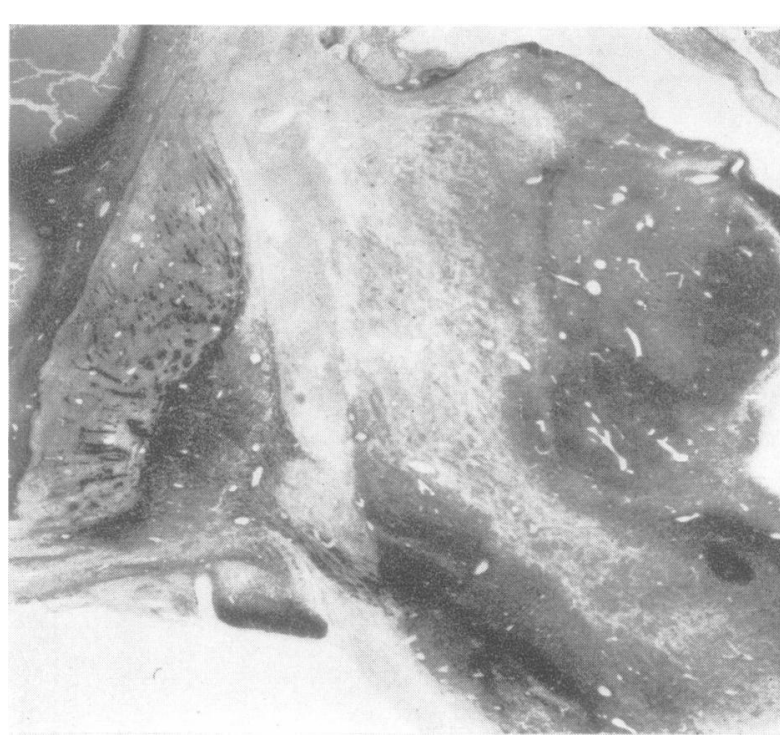

Fig. 6

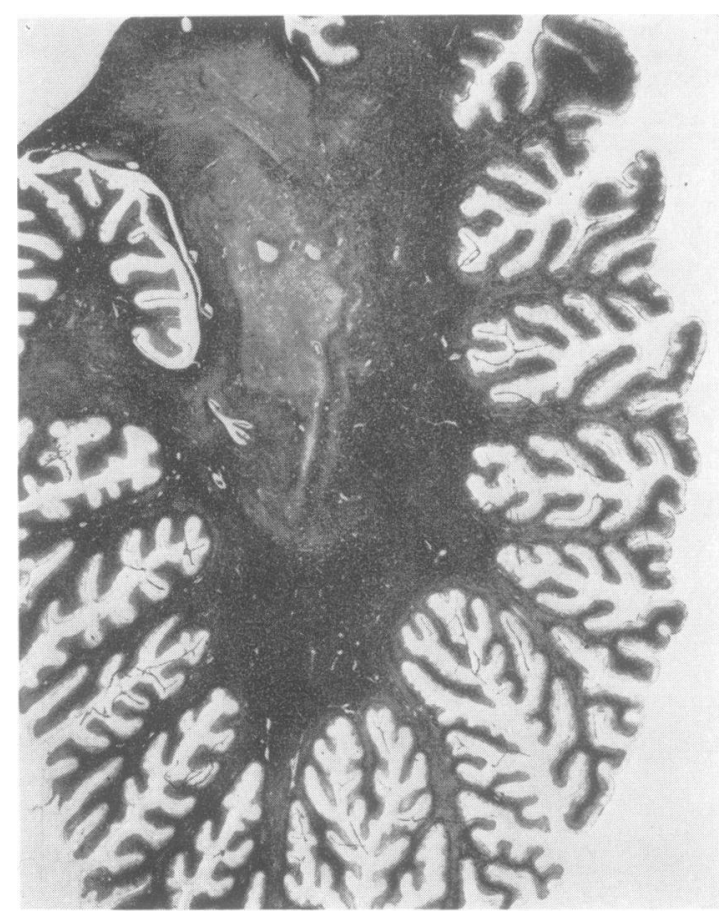

FIG. 8

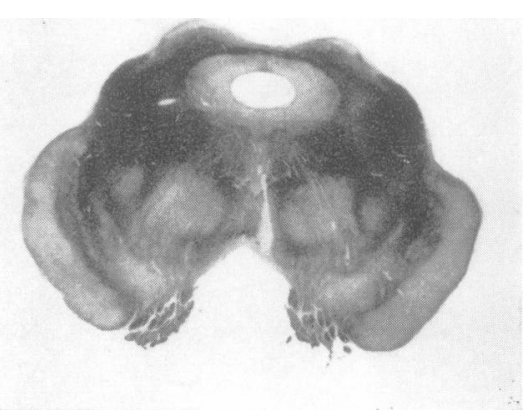

Fig. 7

FIG. 5.-Case 1. Occipital lobe showing loss of myelinated fibres in the optic radiation and periventricular region. Kultschitskivo $\mathrm{Pal} \times \mathbf{1 . 4}$.

FIG. 6.-Case 3. Basal ganglia. There is severe loss of myelinated fibres in the internal capsule, cerebral peduncle, and lateraf thalamic nucleus. The optic tract and globus pallidus are less affected. The putamen is well preserved. Kultschitsky-Pal
$3 \cdot 2$

FIG. 7.-Case 1. Midbrain showing severe loss of myelinated fibres in the cerebral peduncles, substantia nigra, and red nucle Kultschitsky-Pal $\times 2$.

FIG. 8.-Case 3. Intense fibrous gliosis in the severely demyelinated cerebellar white matter and dentate nucleus. Holzer $\times \mathbf{3 \cdot 2}$. 


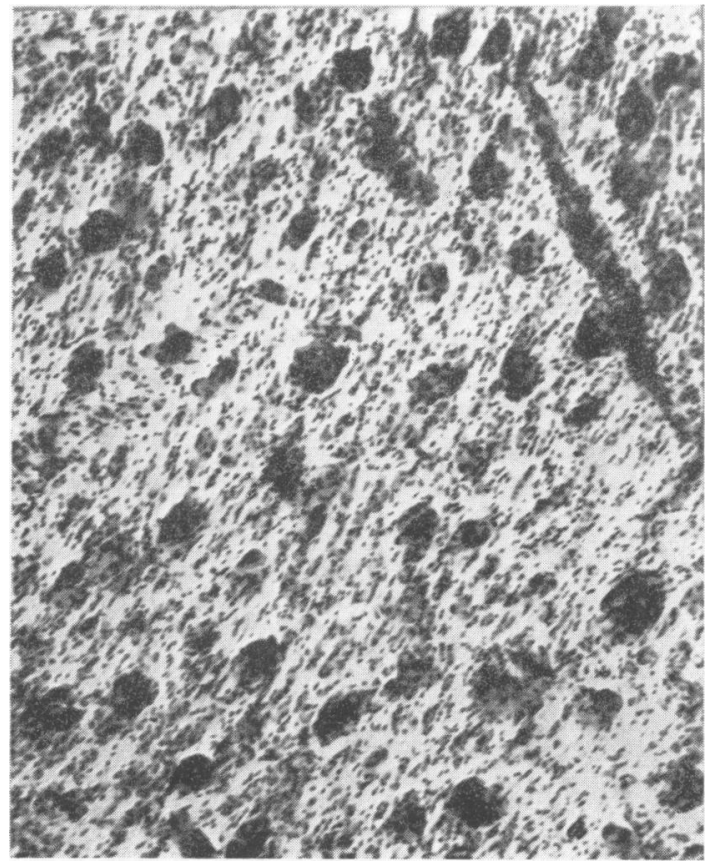

FIG. 9

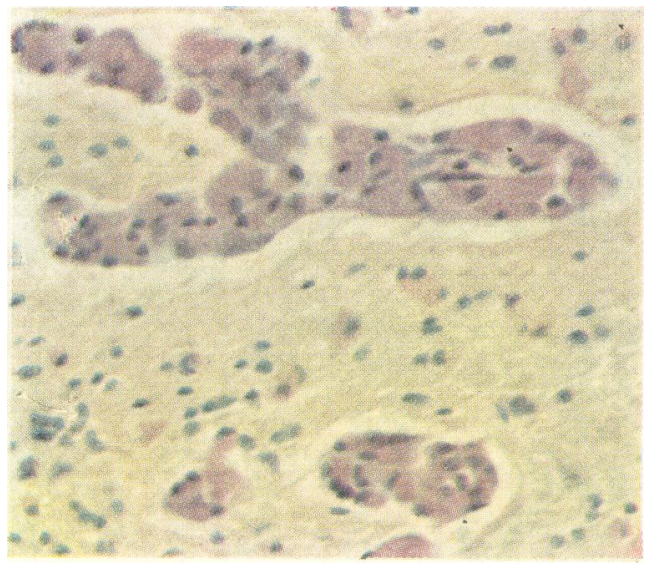

FIG. 10

FIG. 9.-Case 2. The degenerated cerebral white matter contains numerous packets of globoid and epithelioid cells. Carbol azure $\times 74$.

Fig. 10.-Case 3. Typical cell packets around small vessels in the white matter. P.A.S. and haematoxylin $\times 190$.

Fig. 11.-Case 3. Packet containing one globoid and several epithelioid cells. P.A.S. and haematoxylin $\times 480$.

FIG. 12.-Case 1. Large globoid cell. P.A.S. and haematoxylin $\times$ 1,230 .

Fig. 13.-Case 1. The corpus callosum contains an area of tumourlike cell density. P.A.S. and haematoxylin $\times 35$.

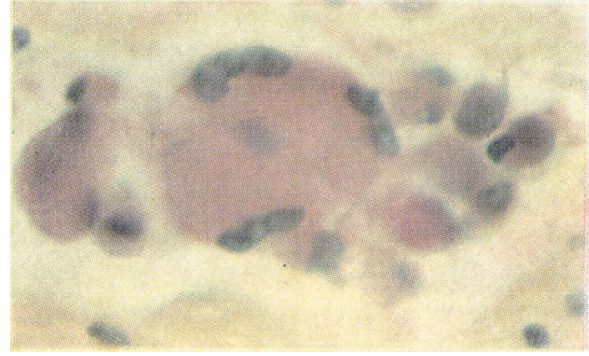

FIG. 11

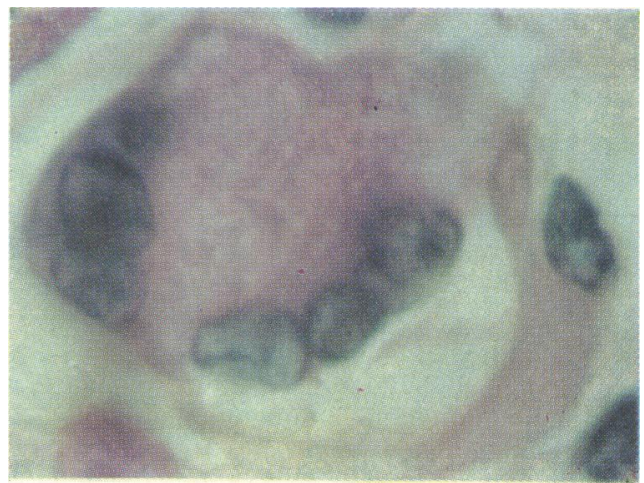

FIG. 12

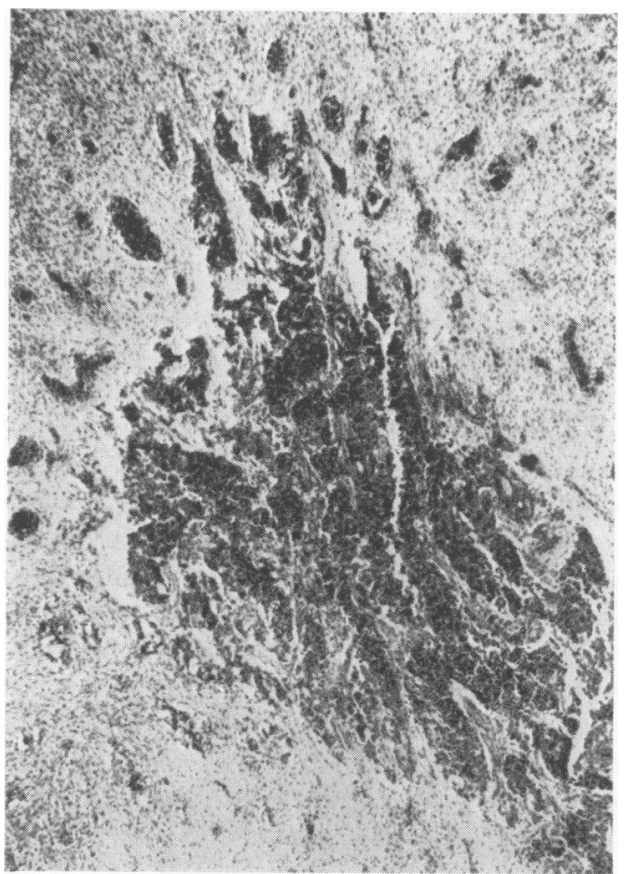

FIG. 13 


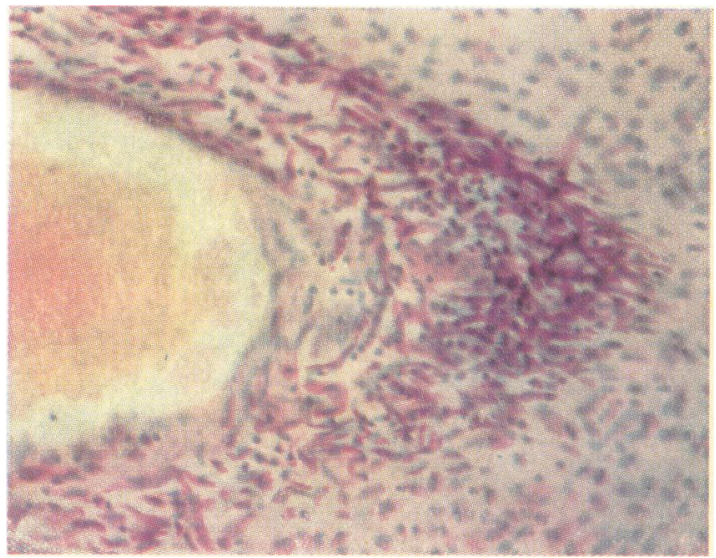

FIG. 14

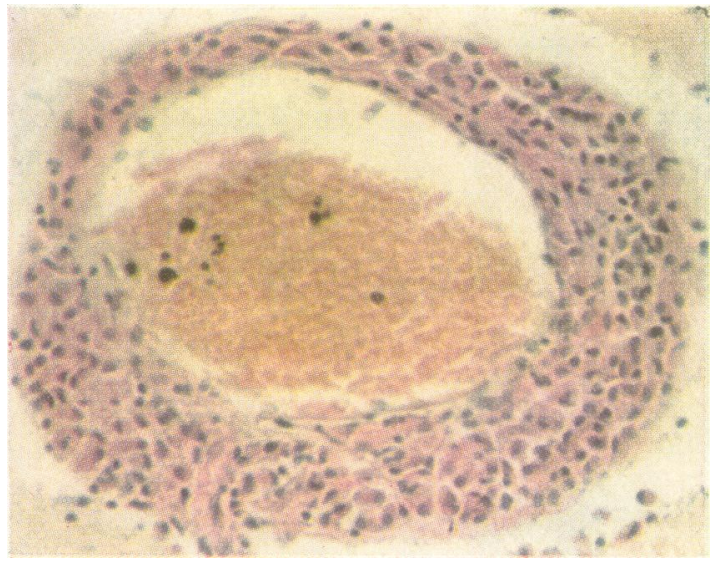

FiG. 16

P.A.S. and grey with Sudan black, and was unaffected by lipid solvents. Smaller mononuclear cells corresponding to Greenfield's (1958) definition of epithelioid cells were also found within the packets. These cell packets were centred only around the smaller vessels, usually precapillaries, the scanty reticulin fibrils of which were confined to the vessel wall and did not surround the globoid cells. The cell packets were not uniformly distributed throughout the degenerated white matter and were often absent from large areas, though isolated mononuclear and multinucleated cells were diffusely scattered throughout the tissues. The corpus callosum in Case 1 included an area in which globoid and epithelioid cells, together with swollen astrocytes and microglia, formed a dense, tumour-like, cellular mass (Fig. 13). Globoid cells were not found within the VirchowRobin spaces of the larger vessels.

There was a remarkable difference in our cases in regard to the type of cells present in the outer coats

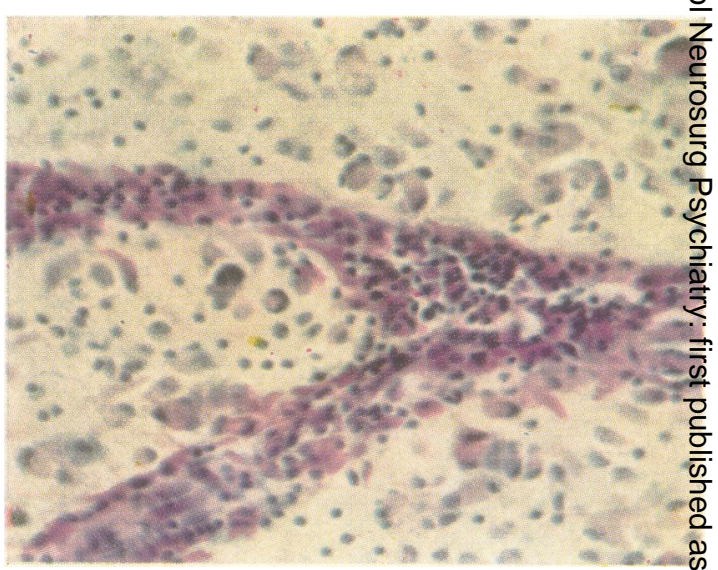

FIG. 15

FIG. 14.-Case 1. Spindle-shaped adventitial cells of a large ve the cerebellar white matter, containing crimson granīles P.A.S. and haematoxylin $\times 190$.

FIG. 15.-Case 1. Small vessel in frontal white matter, showin crimson material in adventitial cells and pink material in globoca and epithelioid cells. P.A.S. and haematoxylin $\times 190$.

FIG. 16.-Case 3. A dense cuff of lipid-laden mononuclear surrounding a vein of the central white matter. P.A.S. and haematoxylin $\times 190$.

of the larger vessels of the white matter. In Cases and 2, but not in Case 3, many of the veins showe a thickening of the adventitial coat due to the presence of numerous spindle-shaped cells filled wit $\overrightarrow{\mathbf{B}}$ granules staining a brilliant crimson with P.A.S (Figs. 14 and 15). This intense colour was never see in the globoid, epithelioid, or microglia cells of the white matter. No transition could be traced betwee these bipolar cells and epithelioid cells. On the othe hand, in Case 3, the veins of the cerebral and cerebellar centre were usually surrounded by dense cuffs. of exclusively mononuclear cells which resembled in their form and staining reactions the epithelioid cels of the cell packets (Fig. 16). Unlike the latter, these closely packed mononuclear cells were enclosed by reticulin fibrils and were sharply separated by ther from the surrounding tissue. No granular spindleo shaped cells were seen in any vessel of Case 3, no? were the dense perivascular aggregations of roungy cells found in the first two cases. 
Changes in Grey Matter.-The cerebral cortex appeared to be normal as regards arrangement and number of nerve cells. Myelination of the radial bundles was extremely poor and the supraradial fibres were not demonstrable.

In the thalamus nerve cells had disappeared except in the nuclei of the midline. This was accompanied by an intense fibrillary and cellular gliosis.

The small nerve cells of the caudate nucleus and putamen in Cases 1 and 2 and the caudate nucleus of Case 3 were severely depleted and large fibrous astrocytes were present in the grey matter. In Case 2 abundant droplets of neutral fat were present in the caudate nucleus and globus pallidus.

The brain-stem nuclei were intact except for severe degeneration of the inferior olives in Cases 2 and 3.

The cerebellar cortex in Cases 1 and 2 appeared normal except for a mild proliferation of the Bergmann fibrils and the presence of fat-laden microglial cells in the molecular layer. In Case 3, however, the gliosis was intense and the granular layer rarefied, particularly in the vermis. Many folia also showed a loss of Purkinje cells, some of the survivors having axonal and dendritic swellings. In all cases the dentate nuclei had almost completely degenerated.

The nerve cells of the spinal cord showed no significant change.

Strongly P.A.S.-positive granules were seen in the adventitial fibroblasts of the vessels in many parts of the grey matter (Cases 1 and 2 only). These changes were very conspicuous in the thalamus, and less marked in the cerebral cortex, granular layer of the cerebellum, corpus striatum, brain-stem, and spinal cord.

Meninges.-In celloidin sections from Case 1 a few of the arachnoidal cells were seen to contain strongly P.A.S.-positive granules.

Eye (Case 2).-Except for a marked loss of ganglion cells the retina appeared normal. A few glial cells containing P.A.S.-positive granules were seen near the optic disc in the superficial part of the nerve fibre layer.
Visceral Organs.-Histological examination in Case 2 of heart, liver, kidneys, pancreas, spleen, lymph node, bone marrow, pituitary, adrenal, thyroid, and ovary revealed no abnormality. The lung showed the changes of bronchopneumonia and no multinucleated cells were found.

\section{Chemistry}

Methods. - Total lipid hexose was estimated by the method of Mallov, McKibbin, and Robb (1953). Neutral hexose was estimated by a modification of the technique of Radin, Lavin, and Brown (1955). By this method the acid carbohydrate lipids, namely, ganglioside and cerebron sulphuric acid, are separated from the neutral carbohydrate lipids (cerebroside). Lipid extracts obtained by hot extraction with $2 \mathrm{CHCl}_{3}: 1 \mathrm{MeOH}$ were used, extraction with acetone being omitted. The dried cerebroside was hydrolysed and the hexose estimated by the method of Mallov et al. (1953). Lipid sulphur was estimated by a modification of the method of Cuthbertson and Tompsett (1931). The lipid extract was ashed with $\mathrm{HNO}_{3}$ and a small amount of $\mathrm{NaCl}$, the ash taken up in $4 \%$ trichloracetic acid and the precipitated sulphur estimated colorimetrically. More than $10 \mu \mathrm{g}$. S. must be taken for the precipitation to be complete (Dodgson and Spencer, 1953), and the aliquot taken for colorimetric estimation should contain about $2 \mu \mathrm{g}$. S. Hexosamine, neuraminic acid, and other substances analysed were estimated by methods cited in previous papers (Tingey, 1956, 1959). Sphingomyelin was assessed by difference of the choline fractions and does not include cephalin B.

Time in Formalin.-The brains from Cases 1 and 3 had been fixed in $10 \%$ formol saline for two weeks and 10 months respectively before analysis was started. The brain from Case 2 was obtained unfixed. Control material consisted of two normal brains of infants dying at 9 months, one unfixed, the other fixed in formalin for approximately $\mathbf{1 2}$ months. Use has also been made of a normal brain of a child of 12 months which had been fixed in formalin for about a year.

\section{Results}

Glycolipids.- In the white matter the neutral hexose has remained at a surprisingly high figure compared with the normal, while in the cerebral cortex it shows an absolute increase over normal (Table I). In the fresh brain (Case 2) both the lipid

TABLE I

GLYCOLIPIDS

\begin{tabular}{|c|c|c|c|c|}
\hline & $\begin{array}{l}\text { Normal ( } 9 \text { months) } \\
\text { Formalin }\end{array}$ & $\begin{array}{l}\text { Case } 1 \text { (9 months) } \\
\text { Formalin }\end{array}$ & $\begin{array}{c}\text { Case } 2 \text { (6 months) } \\
\text { Fresh }\end{array}$ & $\begin{array}{c}\text { Case } 3 \text { (13 months) } \\
\text { Formalin }\end{array}$ \\
\hline $\begin{array}{l}\text { Total lipid hexose (g./100 g. dry tissue) } \\
\text { Neutral hexose (g./100 g. dry tissue) } \\
\text { Lipid hexosamine (g./100 g. dry tissue) } \\
\text { Neuraminic acid (g./100 g. dry tissue) } \\
\text { Lipid sulphur (g./100 g. dry tissue) }\end{array}$ & $\begin{array}{l}1.85(1 \cdot 03) \dagger \\
0 \cdot 75(0 \cdot 20) \\
0.077(0 \cdot 172) \\
0 \cdot 132 *(0.483) \\
0.117(0.093)\end{array}$ & $\begin{array}{l}1 \cdot 51(1 \cdot 29) \\
0 \cdot 86(0.44) \\
0.055(0 \cdot 121) \\
0 \cdot 106(0.384) \\
0.059(0.083)\end{array}$ & $\begin{array}{l}1.26(0.97) \\
0.68(0 \cdot 36) \\
0 \cdot 137(0 \cdot 148) \\
0.286(0 \cdot 426) \\
0.082(0.046)\end{array}$ & $\begin{array}{l}0.85(0.56) \\
0.66(0.36) \\
0.077(0.146) \\
0.181(0.392) \\
0.038(0.028)\end{array}$ \\
\hline
\end{tabular}

†Figures for cerebral cortex are in brackets. Asterisk indicates 1 year control. 
hexosamine and the neuraminic acid are substantially increased in the white matter. The lipid sulphur is reduced in the white matter of Cases 1 and 3 and in the cortex of Cases 2 and 3.

Phospholipids.-Owing to the well-recognized effect of formalin upon phosphatides, only the results obtained from unfixed material have been included in Table II. The sphingomyelin in the white matter is reduced by a half compared with the normal. The lecithin is not affected. The sphingomyelin of Cases 2 and 3 (not in Table II) also showed a similar reduction in the white matter $(0.8$ and 0.9 respectively).

TABLE II

PHOSPHOLIPID

\begin{tabular}{|c|c|c|}
\hline & $\begin{array}{l}\text { Normal } \\
\text { (9 Months) } \\
\text { Fresh }\end{array}$ & $\begin{array}{l}\text { Case } 2 \\
\text { (6 Months) } \\
\text { Fresh }\end{array}$ \\
\hline $\begin{array}{l}\text { Total phospholipid (g./100 g. dry tissue) } \\
\text { Lecithin (g./100 g. dry tissue) } \\
\text { Sphingomyelin (g./100 g. dry tissue) }\end{array}$ & $\begin{array}{l}20.7(19.5) \dagger \\
8.2(7.8) \\
1.7(1.0)\end{array}$ & $\begin{array}{l}15.0(19.7) \\
7.6(10.7) \\
0.8(0.3)\end{array}$ \\
\hline
\end{tabular}

†Figures for cerebral cortex are in brackets.

Other Estimations.-The free cholesterol is reduced in the white matter of the three cases (Table III). No appreciable change is present in ester cholesterol. In Cases 1 and 2 there is an increase in the non-lipid hexosamine in both the white and grey matter. In the fresh brain (Case 2) there is a four-fold increase in the water-soluble hexosamine of the white matter. in that the loss of myelinated axons tends to be widespread throughout the central nervous systen? and is particularly severe in the cerebrum, the cereo bellum, and the cortical projection fibres. From the chemical standpoint the leucodystrophies also differ from true demyelinating diseases in their raised level of lipid hexosamine, a peculiarity which they shares with certain lipidoses (Edgar, 1957).

It has already been pointed out that the patho gnomonic histological feature of Krabbe's disease is: the presence of packets of globoid and epithelioide cells around the smaller cerebral vessels in the degenerated white matter, but the final classification of this disease will doubtless depend upon the identification of the predominant chemical ab $\Phi$ normality. Histochemical studies (Diezel, 1955 Stammler, 1956) have suggested that the macrophage cells, whether perivascular or diffusely scattered? contain a substance having the properties of $\vec{a}$ cerebroside bound to protein. Chemical analysis of brains in this disease has not, however, give uniform results.

A reduction in the amount of cerebroside was reported by Klenk in one of Hübner and Halleris vorden's (1956) cases and by Brante in the caseopot Kaijser and Lundquist (1948). In the chem analyses of seven other cases of Krabbe's disease recorded by Cumings (1960), only the 'galactgse' cerebroside' (calculated from the total lipid hexose was estimated. This was found to be substantial increased in both cortex and white matter in the

TABLE III

OTHER ESTIMATIONS

\begin{tabular}{|c|c|c|c|c|c|}
\hline & $\begin{array}{l}\text { Normal } \\
\text { (9 Months) } \\
\text { Formalin }\end{array}$ & $\begin{array}{l}\text { Normal } \\
\text { (9 Months) } \\
\text { Fresh }\end{array}$ & $\begin{array}{l}\text { Case 1 } \\
\text { (9 Months) } \\
\text { Formalin }\end{array}$ & $\begin{array}{l}\text { Case } 2 \\
\text { (6 Months) } \\
\text { Fresh }\end{array}$ & $\begin{array}{c}\text { Case } 3 \\
\text { (13 Months) } \\
\text { Formalin }\end{array}$ \\
\hline
\end{tabular}

\section{Discussion}

In their main clinical and histological features these cases conform to other reported examples of Krabbe's disease. This condition is a leucodystrophy, a term originally introduced by Bielschowsky and Henneberg (1928) to signify an inherited disease of the white matter, in which the predominant products of abnormal myelin metabolism are not the usual scarlet-staining lipids found in disseminated sclerosis or Schilder's disease. Krabbe's disease also conforms to the topographical criteria of a leucodystrophy set out by Poser and van Bogaert (1956), 3-year-old case of Blackwood and Cumings (1954 but in the six younger patients the cerebroside levelis were considered by Cumings to be normal. In ou? own Case 3 the 'galactose cerebroside' was markedis reduced in the white matter, yet the neutral cere broside fraction still remained at an almost norma level. This finding suggests that neutral cerebrosides is the glycolipid which tends to be selectively reo tained in the diseased tissues. In normal brain neutral cerebroside increases steadily with chronos logical age during early childhood and appears to be a better index of myelination than the total lipie 
TABLE IV

NEUTRAL AND TOTAL HEXOSE IN NORMAL WHITE MATTER

\begin{tabular}{|c|c|c|c|c|c|c|}
\hline & Neonatal & 3 Months & 9 months & 12 months & $2 \frac{1}{2}$ Years & 4 Years \\
\hline $\begin{array}{l}\text { Neutral hexose (g./100 g. dry tissue) } \\
\text { Total lipid hexose (g./100 g. dry tissue) }\end{array}$ & $\begin{array}{l}0.33 \\
1.05\end{array}$ & $\begin{array}{l}0.49 \\
2 \cdot 10\end{array}$ & $\begin{array}{l}0.75 \\
1.85\end{array}$ & $\begin{array}{l}1 \cdot 25 \\
2 \cdot 10\end{array}$ & $\begin{array}{l}1 \cdot 53 \\
2.43\end{array}$ & $\begin{array}{l}2 \cdot 37 \\
3 \cdot 60\end{array}$ \\
\hline
\end{tabular}

hexose (Table IV). In metachromatic leucoencephalopathy we have found a reduction in this substance (Norman, Urich, and Tingey, 1960). Thus in the present cases of Krabbe's diseases there is the paradox of a centrum ovale grossly deficient in stainable myelin yet containing neutral cerebroside in relatively large amounts.

A central problem of Krabbe's disease is the derivation of the distinctive globoid cell packets. Such formations are not found in any other type of demyelinating disease or leucodystrophy. If globoid cells are derived from the microglia, as Blackwood and Cumings (1954) believe, it is strange that they should be centred almost exclusively around the smaller vessels, usually those of precapillary size. Blackwood (1954) and Blackwood and Cumings (1954) described in their case extracellular masses of P.A.S.-positive material, and the silver impregnation preparations suggested that these masses became engulfed by marginal microglial cells and eventually turned into globoid giant cells. We saw no extracellular material of this sort in our cases, and Peiffer (1957) has suggested that when free masses of 'cerebroside' are seen in this condition they are merely tangentially cut globoid cells. Opinion seems now to favour the view that these cells are derived from the vascular adventitia (Hallervorden, 1957; Diezel, 1955; Stammler, 1956; Greenfield, 1958). Hallervorden (1948) was struck by the resemblance between globoid and Gaucher cells, and it is well established that in the infantile form of the latter disease the adventitial cells of blood vessels in the cerebral white matter store a cerebroside-like substance (Norman, Urich, and Lloyd, 1956). Diezel (1956) believes that in Krabbe's disease 'the globoid cells have secondarily absorbed the glycolipids from the decomposed myelin sheaths, whereas the cerebrosides in the Gaucher cells arise primarily as a result of a cellular enzymatically caused metabolic disturbance'. Recent experiments by Austin, Leyfeldt, and Maxwell (1961) have given some support to this view. In a personal communication Austin states that cells closely resembling globoid and epithelioid cells were produced in the white matter of rats by the intracerebral injection of both natural and synthetic cerebrosides, and not by other lipids such as ganglioside, sphingomyelin, sulphatides, or cholesterol. Austin points out that these experimental findings cannot in themselves establish that human globoid cells arise as a specific reaction to the presence of cerebrosides. Nevertheless, it would seem that a pathogenetic factor of considerable importance has been disclosed.

A similar problem of interpretation was raised in our first two cases by the peculiar adventitial cell changes in the larger vessels of the white matter. Numerous spindle-shaped, fibroblastic cells contained granules staining much more intensely with the periodic-acid-Schiff method than the globoid or macrophage cells found elsewhere in the same brain. Stammler (1956) also discovered very marked proliferation of the adventitia of the larger vessels in his case of Krabbe's disease, and favoured the explanation that this was a response to the products of myelin breakdown, rather than a primary storage of cerebroside, as in a true lipidosis. Yet in other leucodystrophies and demyelinating diseases, in which cerebroside is present in the tissues either as a product of myelin breakdown or of defective anabolism, vascular reactions of these types are not found. It appears to us that the possibility cannot be ruled out that in Krabbe's disease there may be some additional or perhaps variable abnormality in the adventitial cells themselves, owing to which cerebroside is hindered in its passage through the vessel walls into the blood stream. Such a factor would account for the variation in the number of globoid cells present in different fields in the same brain and for the variable type of adventitial reaction found in different cases of the disease.

Finally, it may be pointed out that there is no histological evidence of neuronal storage in this condition. While it is known that in infantile Gaucher's disease nerve cells may degenerate and disappear without having previously stored lipid, there is little to suggest that this process occurs in Krabbe's disease. The degeneration of the dentate nucleus and inferior olive which has also been found in some other cases of the disease could be attributed to severe axonal damage. Similarly, the diffuse cerebellar atrophy in Case 3 might also have been secondarily introduced, since it was not sufficiently marked to invite comparison with the almost complete degeneration of the granular layer sometimes seen in amaurotic idiocy and metachromatic leucoencephalopathy. Striatal lesions were noted in our cases, as in that of Collier and Greenfield (1924), but it would be difficult to rule out the effects of anoxia 
in their causation. In view of these non-specific neuronal changes and in the absence of visceral storage it does not seem justifiable to class Krabbe's disease as a lipidosis. Nor has chemical analysis shown a consistent increase in cerebroside over normal. The condition remains primarily a disease of myelinated axons.

\section{Summary}

The histological and chemical features of Krabbe's disease (globoid cell leucodystrophy) have been studied in three children, two of whom were siblings. Chemical analysis of the degenerated cerebral white matter in all three cases showed that neutral cerebroside was present in approximately normal amount, though there was a reduction in most of the other myelin lipids. In one brain which had been analysed before fixation in formalin the white matter contained substantially increased amounts of all the hexosamines and of neuraminic acid.

Histological examination in all cases demonstrated the characteristic globoid and epithelioid cell packets around vessels of precapillary size. In two cases the adventitial coat of the larger vessels in the white matter was thickened and contained spindle-shaped cells filled with granules staining more intensely with the periodic-acid-Schiff method than the globoid cells. It is considered that both types of cell are derived from the vascular adventitia, that they arise as a response to the presence of cerebroside in the tissues, and that there may be an associated abnormality in the adventitial cells themselves to account for this storage of lipid.

We are greatly indebted to Professor P. M. Daniel, Dr. Victoria Smallpiece, Dr. I. H. Gosset, and Dr.
W. E. Bryan, for sending us pathological material an for access to their clinical records. This work wg carried out with the help of the Nuffield Foundation. $\stackrel{\mathbb{D}}{\square}$

\section{REFERENCES}

Austin, J., Leyfeldt, D., and Maxwell, W. (1961). J. Neuropath, 20 284.

Bielschowsky, M., and Henneberg, R. (1928). J. Psychol. Neur@ (Lpz.), 36, 131.

Blackwood, W. (1954). Proceedings of the 1st International Congress of Neuropathology, Rome, 1952, Vol. 1, p. 265. and Cumings, J. N. (1954). J. Neurol. Neurosurg. Psychiat 17,33 .

Bullard, W. N., and Southard, E. E. (1906). J. nerv. ment. Dis., 3흘 188

Collier, J., and Greenfield, J. G. (1924). Brain, 47, 489.

Cumings, J. N. (1960). In Modern Scientific Aspects of Neurolog p. 342. Arnold, London.

Cuthbertson, D. P., and Tompsett, S. L. (1931). Biochem. J., 25: 1237.

Diezel, P. B. (1955). Virchows Arch. path. Anat., 327, 206.

(1956). In Cerebral Lipidosis, p. 64. Blackwell, Oxford.

Dodgson, K. S., and Spencer, B. (1953). Biochem. J., 55, 436.

Edgar, G. W. F. (1957). In Cerebral Lipidoses, ed L, 436. J. N. Cumings, and A. Lowenthal, p. 186. Blackwell, Oxfort

Ferraro, A. (1927). J. nerv. ment. Dis., 66, 329, 479, and 616.

Greenfield, J. G. (1958). Neuropathology, p. 463. Arnold, Londo $\overrightarrow{.1 .}$

Guillain, G., Bertrand, I., and Gruner, J. (1941). Rev. neurol., $7 \mathrm{z}_{\mathrm{B}}$ 401 .

Hallervorden, J. (1948). Verh. dtsch. Ges. Path., 32, 96.

(1957). In Henke F. and Lubarsch O. Handbuch der spezielle pathologischen Anatomie und Histologie, Band 13, Teil to

Hübner, O., and Hallervorden, J. (1956). Zbl. allg. Path. Anat., 9⿺ 461.

Kaijser, K., and Lundquist, C. W. (1948). Nord. Med., 39, 1355.7 .

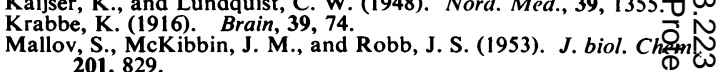
$201,829$. Norman, R. M., Urich, H., and Lloyd, O. C. (1956). J. Path. B⿺辶⿸广巳廿巾0

$\overline{\text { Peiffer, J. }}$, and Tingey, A. H. (1960). Brain, 83, 369. Cumings and A. Lowenthal, p. 67. Blackwell, Oxford.

Poser, C. M., and Bogaert, L. van (1956). Acta psychiat. scand. 316 285.

Radin, N. S., Lavin, F. B., and Brown, J. L. (1955). J. biol. Chem $217,789$.

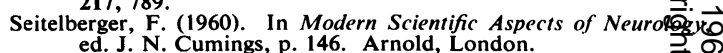
Stammler, A. (1956). Disch. Z. Nervenheilk., 174, s0s.

Tingey, A. H. (1956). J. ment. Sci., 102, 851,

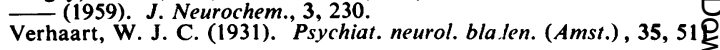

